\title{
Evaluation of greenhouse gas emission by ethanol production from sugarcane (case study of Minas Gerais, Brazil)
}

\author{
Juan C.C.Garcia ${ }^{1}$, Eduardo v. Sperling ${ }^{2 *}$ \\ ${ }^{1}$ PhD Student, Federal University of Minas Gerais, Belo Horizonte, Brazil \\ ${ }^{2}$ Lecturer, Department of Sanitary and Environmental Engineering, Federal University of Minas Gerais, Brazil \\ *Corresponding author. Tel: +55 31 34091019, Fax: +55 31 34091879, E-mail: eduardo@desa.ufmg.br
}

\begin{abstract}
The paper presents an evaluation of greenhouse gas emission during the industrial process of ethanol production from sugarcane crops. The production of biofuels is experiencing an increasing trend in most regions of the world, following the need of the optimization of renewable energy from biomass. In Brazil sugarcane is one of the main raw materials for the production of ethanol. The research summarized in this paper was carried out in the period 2008-10 in the State of Minas Gerais, Brazil. The tool Ecoinvent has been used for the estimation of the environmental magnitude of the components of bioethanol production. Moreover a field survey has been carried out, which involved the visit to 11 selected distilleries, together with the application of questionnaires related to the whole ethanol production process and to the utilization of chemical components and by-products. The total emission of $\mathrm{CO}_{2}$ eq (representing the whole amount of greenhouse gases: $\mathrm{CO}_{2}, \mathrm{CH}_{4}$ and $\mathrm{N}_{2} \mathrm{O}$ ) could be estimated in $1540 \mathrm{~kg} /$ ha.year. The key sources of greenhouse gas emissions in the bioethanol production are sugarcane burning and use of fuels, which account for more than $50 \%$ of total emissions. This shows a clear environmental limitation in the process of sugarcane utilization.
\end{abstract}

Keywords: Ethanol, Greenhouse Gases Sugarcane

\section{Introduction}

The environmental constraints related to the explotation of fossile fuels, together with the current concerns regarding the massive production of hydropower lead to the convenience of searching alternative energy sources. In this sense the production of biofuels is experiencing an increasing trend under a global perspective. Countries like Brazil, which present large agricultural areas, are intensively researching the optimization of renewable energy from biomass. In Brazil sugarcane is one of the main raw materials for the production of ethanol. The fermentation of sugar into ethanol is one of the earliest organic reactions employed by humanity. Sugarcane is a semiperennial grass of the genus Saccharum, which is native to warm temperate to tropical regions of Asia. They present stout, jointed, fibrous stalks that are rich in sugar. Two countries (Brazil and India) are together responsible for around $50 \%$ of the world sugarcane production. Sugarcane products include table sugar, molasses, alcoholic beverages (e.g. rum) and ethanol. World's ethanol production forecast for 2012 will pass 20 billion gallons and Brazil will be responsible for one third of this amount [1]. The largest single use of ethanol is as motor fuel and fuel additive. Gasoline sold in Brazil contains at least $20 \%$ anhydrous ethanol, which is blended since 1933. In 2003 the country started a massive production of vehicles flex-fuel, which function with gasoline as well as with ethanol. The cane delivered to the processing plant is called burned and cropped and represents $77 \%$ of the mass of the raw cane. The reason for this reduction is that the stalks are separated from the leaves (which are burned and whose ashes are left in the field as fertilizer) and from the roots that remain in the ground to sprout for the next crop. The basic steps for large scale production of ethanol are: microbial fermentation of sugars, distillation and dehydration. Some crops require previous saccharification or hydrolysis of the carbohydrates such as cellulose and starch into sugars. Currently only the sugar (from sugarcane) and starch (from corn) portions can be economically converted to sugars. However there is much activity in the area of cellulosic ethanol, where the cellulose part of a plant is broken down to sugars and subsequently converted to ethanol. Greenhouse gases $\left(\mathrm{CO}_{2}, \mathrm{CH}_{4}\right.$ and $\left.\mathrm{N}_{2} \mathrm{O}\right)$ are generated 
during the agricultural process together with the corresponding inputs manufacturing emissions.

Fig. 1 presents the main steps in conventional ethanol production in Brazil [2].

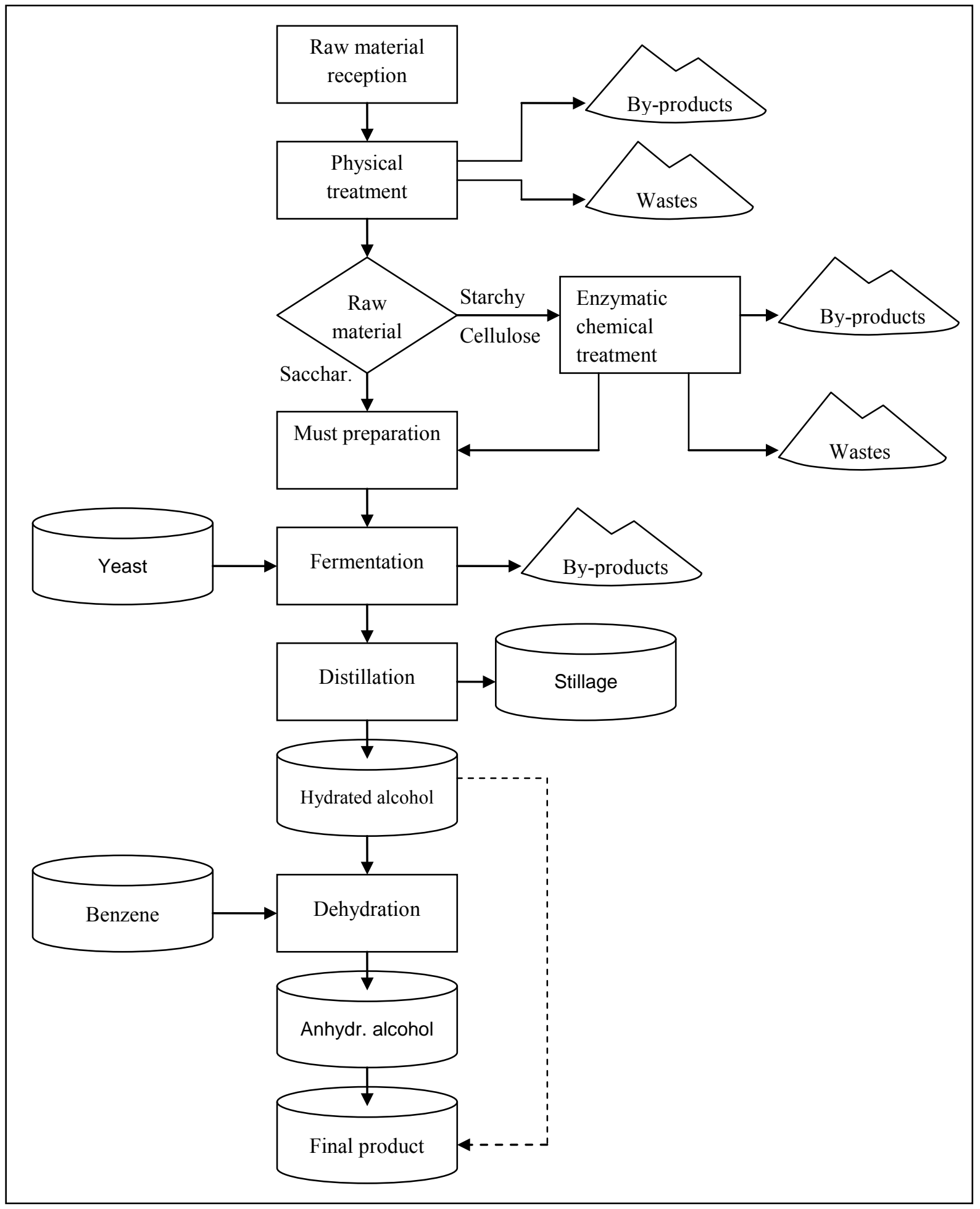

Fig. 1: Technological routes for ethanol production in Brazil

Some international studies $[3,4,5]$ have been dedicated to the evaluation of energetic efficiency and the corresponding mitigation of the emission of greenhouse gases. However 
there is no broad consensus about energetic gains due to ethanol utilization and its impact on generation of greenhouse gases. Major inconsistencies are related to assumptions adopted by the quantification of inputs and outputs in ethanol life cycle [6]. Also technological differences in the local ethanol production process affect the accuracy of the results [7]. Consequently further studies are demanded in order to solve these limitations.

\section{Methodology}

The research presented in this paper was carried out in the period 2008-10 in the state of Minas Gerais, one of the $27 \mathrm{~s}$ tates which forms the Federative Republic of Brazil. Minas Gerais is currently the second largest sugarcane and ethanol producer state in Brazil, being placed after the state of São Paulo. In order to estimate the environmental magnitude of the components of bioethanol production the tool Ecoinvent has been used, which provides data for inputs and outputs of lifecycle of thousands of materials. The field survey involved the visit to 11 selected distilleries in the State of Minas Gerais, together with the application of questionnaires related to the whole ethanol production process and to the utilization of chemical components and by-products.

The first step for the evaluation of greenhouse emission gases in ethanol production was the correct identification of all relevant stages in the agricultural phase and in the sugarcane industrialization. Technological variations in both phases may result in quite different numbers for the emission values. Principles of Life Cycle Evaluation [8] together with IPCC recommendations [9] have been used in this phase. Only the most important greenhouse gases have been considered $\left(\mathrm{CO}_{2}, \mathrm{CH}_{4}\right.$ and $\left.\mathrm{N}_{2} \mathrm{O}\right)$ and total emissions are expressed in $\left(\mathrm{kg} \mathrm{CO}_{2} \mathrm{eq}\right)$ as follows: $1 \mathrm{~kg} \mathrm{CH} \mathrm{CH}_{4}=21 \mathrm{~kg} \mathrm{CO} \mathrm{CO}_{2 \mathrm{eq}}$ and $1 \mathrm{~kg} \mathrm{~N} \mathrm{~N}_{2} \mathrm{O}=310 \mathrm{~kg} \mathrm{CO}_{2 \mathrm{eq}}$ [10]. Emissions estimation assumed 1 ha of cultivated soil as the functional unity. Adopted time span was 6 years, which encompasses seedling application, sugarcane cycle and 4 cycles of agricultural plant resprout. Emissions were calculated using Eq. 1:

$E i=\frac{I j \times n c \times F E j}{6}$

Where: $E i=$ greenhouse gas emission corresponding to activity $(i) i=$ fuel consumption in agricultural operations, fuel consumption in seedling transport, fuel consumption in filtercake, ashes and sediments transport, fuel consumption in lime and fertilizers transport, fuel consumption in irrigation, fuel consumption in mechanical harvest, fuel consumption in loading and sugarcane transport, crop burning, $\mathrm{N}_{2} \mathrm{O}$ emission from soil, seedling production, consumption of chemical products in the industrial phase; $I j=$ consumed quantity of raw materials in each category; $n c=$ number of cycles; $F E j=$ emission factor corresponding to raw material $I j ; j$ = fuel, lime, fertilizers, pesticides, burnt sugarcane during crop and chemical products used in industrial stage.

Emission factors were obtained from Ecoinvent [11] and, when available, from [9]. Ecoinvent is a broad data base which shows environmental loads, including here gaseous emissions associated with lifecycle of agricultural and industrial products. Data about fuel consumption in vehicles and agricultural machines, eventually not available in visited industries, have been extracted from [12]. 


\section{Results and Discussion}

The calculated emissions have been obtained by multiplying activity data (e.g. liters of diesel in a selected agricultural operation) and emission factor (average values found in the Brazilian technical literature).

All researched distilleries send the whole amount of generated filtercake, ashes and sediments to further utilization in sugarcane farming. Average waste generation rates are respectively $2051.63 \mathrm{~kg} / \mathrm{ha} \cdot \mathrm{a}, 659.60 \mathrm{~kg} / \mathrm{ha} \cdot \mathrm{a}$ and $1430.02 \mathrm{~kg} / \mathrm{ha} \cdot$ ano (total $=4141.25 \mathrm{~kg} / \mathrm{ha} \cdot \mathrm{a}$. Average distance between processing plant and agricultural area is $13 \mathrm{~km}$.

For the calculation of gas emission in transport of lime and fertilizers it was assumed the utilization of a $12 \mathrm{t}$ truck, with fuel consumption of $2,5 \mathrm{~km} / \mathrm{L}$ and an average distance of 25 $\mathrm{km}$ between supplier and farming. In a period of 6 years around $3640 \mathrm{~kg}$ load would be transported [12]. All researched farms use wastewater for sugarcane culture irrigation (24 cycles in 6 years). With respect to fertilizers, the emissions have been calculated considering the most frequent chemical inputs used in the country: $\mathrm{N}$ in the ammonium form, $\mathrm{P}_{2} \mathrm{O}_{5}$ and $\mathrm{K}_{2} \mathrm{O}$ [13]. Pesticides have been classified according to their active components and the emissions have been calculated based on literature values [9] (Table 1).

Table 1. Emission of greenhouse gases in lime and fertilizers consumption

\begin{tabular}{ccc}
\hline Inputs & Consumption (kg/ha) & $\begin{array}{c}\text { Gas emission (kg } \\
\left.\mathbf{C O}_{\mathbf{2}} \mathbf{e q} / \mathbf{h a}\right)\end{array}$ \\
\hline Lime & 1520 & 228 \\
Fertilizers & & \\
$\mathrm{N}$ & 84 & 254 \\
$\mathrm{P}_{2} \mathrm{O}_{5}$ & 123 & 328 \\
$\mathrm{~K}_{2} \mathrm{O}$ & 163 & 85 \\
Total & & 895
\end{tabular}

The gaseous emissions from burning activity in sugarcane plantations have been estimated by the corresponding factors for agricultural wastes recommended by IPCC [9]: $2.7 \mathrm{~g} \mathrm{CH}_{4} / \mathrm{kg}$ and $0.07 \mathrm{~g} \mathrm{~N}_{2} \mathrm{O} / \mathrm{kg}$ of dry mass, which is equivalent to $82.82 \mathrm{~g} \mathrm{CO}_{2} \mathrm{eq} / \mathrm{kg}$ considering a combustion factor of $0.80 . \mathrm{CO}_{2}$ emissions are here not taken into account since the emitted carbon will be reassimilated in the next crop. Nitrogen addition to the soil through the use of fertilizers intensifies nitrification and denitrification processes and liberates $\mathrm{N}_{2} \mathrm{O}$ as a byproduct to the atmosphere. $\mathrm{N}_{2} \mathrm{O}$ emissions are around $20 \mathrm{~g}$ per $\mathrm{kg}$ of $\mathrm{N}$ used in the soil [9].

In the present case all energy consumed in the researched factories is generated by burning bagasse (crushed sugarcane), therefore no ga s emission from fossile fuels are registered. Direct $\mathrm{CO}_{2}$ emissions, which are associated with bagasse burning and molasse (sugarcane syrup) fermentation, are not considered in these calculations since, as pointed before, carbon will be reassimilated by the vegetation. Consequently only emissions coupled with the use of chemical products take part in the general account for the indudtrial phase of ethanol production.

Productivity variations in irrigated and non irrigated areas have been also taken into account in loading, transport and sugarcane industrialization. Field research showed that average distances were $18 \mathrm{~km}$ for trucks of 28 and $45 \mathrm{t}$ and $40 \mathrm{~km}$ in the case of heavier trucks $(58 \mathrm{t})$. 
Moreover inputs transport from suppliers to the industries are carried out by $15 \mathrm{t}$ trucks which cover an average distance of $400 \mathrm{~km}$.

After computing the emission of greenhouse gases in all the necessary steps for ethanol production, following number could be estimated: $1539 \mathrm{~kg} / \mathrm{ha}$.year of $\mathrm{CO}_{2}$ eq (representing the whole amount of greenhouse gases: $\mathrm{CO}_{2}, \mathrm{CH}_{4}$ and $\mathrm{N}_{2} \mathrm{O}$ ). Table 1 summarizes the corresponding emissions and percent values in each of the most relevant categories in ethanol production from sugarcane.

Table 2. Emission of greenhouse gases in agriculture and industrialization of sugarcane for ethanol production

\begin{tabular}{ccc}
\hline Category & $\begin{array}{c}\text { Gas emission } \\
\text { (kgCO } \mathbf{2} . \mathbf{e q} / \mathbf{h a . a})\end{array}$ & $\begin{array}{c}\text { \% contribution in total } \\
\text { emission }\end{array}$ \\
\hline Fuel consumption & 337.18 & 21.9 \\
Fertilizers consumption & 298.38 & 19.38 \\
Biocides consumption & 30.39 & 1.97 \\
Crop burning & 434.31 & 28.21 \\
$\mathrm{~N}_{2} \mathrm{O}$ from soil & 331.52 & 21.54 \\
Seedling production & 72.81 & 4.73 \\
Chemical products & 35.01 & 2.27 \\
Total & $\mathbf{1 5 3 9 . 6}$ & $\mathbf{1 0 0}$ \\
\hline
\end{tabular}

\section{Conclusions}

It can be seen that the key sources of greenhouse gas emissions in the bioethanol production are sugarcane burning, fuel consumption, $\mathrm{N}_{2} \mathrm{O}$ liberation from soil and fertilizers consumption, which account for more than $90 \%$ of total emissions. One of the learning points of this research is that the consideration of other technological scenarios can lead to significant differences in the quantification of greenhouse gases emissions. Moreover, in spite of favourable points in the utilization of ethanol, there are clearly environmental limitations in the process of sugarcane utilization, which are represented by the possibility of the generation of greenhouse gases during the lifecycle of biofuels production.

\section{References}

[1] Sites of OECD (www.oecd.org) and FAO (www.fao.org), 2010

[2] Esteves, O. Exergetic analysis of ethanol production from sugarcane (in Portuguese), Federal University of Minas Gerais, School of Engineering, Brazil, Master Course in Nuclear Sciences and Techniques, 1996. 120 p.

[3] Kaltschmitt, M., Reinhardt, G., Stelzer, T., Life cycle analysis of biofuels under different environmental aspects, Biomass and Bioenergy 12, 1997, pp. 21-34

[4] Kadam, K. L., Environmental benefits on a life cycle basis of using bagasse-derived ethanol as a gasoline oxygenate in India, Energy Policy, 2002, pp. 371-384

[5] Luo, L., Voet, E., Huppes, G., Life cycle assessment and life cycle costing of bioethanol from sugarcane in Brazil, Renewable and Sustainable Energy Reviews, 2008

[6] Liska, A. J., Cassman, K. G., Towards standardization of life-cycle metrics for biofuels: greenhouse gas emissions mitigation and net energy yield, Journal of biobased materials and bioenergy, 2008. pp. 187-203 
[7] Soares, L. H. de B.. Mitigation of greehouse gas emissions by the use of ethanol from sugarcane (in Portuguese). Technical Paper 27, Ministry of Agriculture, 2009

[8] United States Environmental Protection Agency, Life Cycle Assessment: principles and practice. Cincinnati, USEPA, 2006. 88 p.

[9] Intergovernamental Panel on Climate Change (IPCC), Guidelines for National Greenhouse Gas Inventories, National Greenhouse Gas Inventories Programme, 2006

[10] Intergovernamental Panel on Climate Change (IPCC), Climate Change 2007: The Physical Science Basis, Cambridge, Cambridge University Press, 2007

[11] Institut für Umweltinformatik, Institut für Energie \& Umweltforschung. Ecoinvent v2.01a for Umberto 5.5. Hamburg, 2006. 1 CD-ROM.

[12] Macedo, I. C.; Leal, M.; Silva, J. Balance of the emission of greenhouse gases in production and utilization of ethanol in Brazil (in Portuguese), Environmental Agency of the State of São Paulo, 2004. 32 p.

[13] Oliveira, M. W., Mineral nutrition and fertilization of sugarcane (in Portuguese), Agricultural News, Belo Horizonte, Brazil. 239, 2007, p. 30-43 